\title{
Effect of Modified Atmospheric Packaging on Seed Longevity of Onion (Allium cepa L.) cv. Arka Kalyan
}

\author{
Koteshi Lamani*, V. K. Deshpande, N. K. Biradar Patil and T. R. Shashidhar \\ Department of Seed Science and Technology, University of Agricultural Sciences, \\ Dharwad-580005, Karnataka, India \\ *Corresponding author
}

\begin{tabular}{|l|}
\hline Ke y w o r d s \\
Cold storage, \\
Onion, Seed vigor, \\
Vaccum
\end{tabular}

\section{A B S T R A C T}

The experiment was carried out to understand the storability of onion seeds by subjecting to different modified atmospheric storage conditions with different combination of gases like carbon dioxide, oxygen and nitrogen at different concentrations. The experiment was consisted of seed storage of onion (Arka Kalyan) under modified atmospheric storage conditions. There were 15 treatments and the experiment was carried out in Completely Randomized Block Design in four replications and observations on various seed quality parameters were recorded bimonthly. Seed quality parameters differed significantly due to modified atmospheric storage conditions in all the 12 months of storage irrespective of the modified atmospheric conditions. The seeds stored in Cold storage $\left(\mathrm{T}_{15}\right)$ recorded maximum, thousand seed weight $(3.83 \mathrm{~g})$, seedling vigour index-I of $(1,394)$, seedling vigour index-II of $(1,605)$, field emergence of $(78.51 \%)$ and lowest seed borne infection of $(0.0)$ seed moisture content $(6.11 \%)$, electrical conductivity $\left(\mathrm{d} \mathrm{Sm}^{-1}\right)(0.884)$ after twelve months of storage period followed by $\mathrm{T}_{1:} 80 \% \mathrm{CO}_{2}: 05 \% \mathrm{O}_{2}: 15 \% \mathrm{~N}_{2}(72.32 \%)$ and seeds stored in vacuum $\left(\mathrm{T}_{13}\right)$.The lowest thousand seed weight $(2.63 \mathrm{~g})$, seedling vigour index-I recorded (623), seedling vigour index-II recorded (587), field emergence recorded $(40.67 \%)$ and highest seed borne infection of (37.71), seed moisture content $(8.17 \%)$, electrical conductivity $\left(1.020 \mathrm{~d} \mathrm{Sm}^{-1}\right)$ was noticed in seed stored in cloth bag $\left(\mathrm{T}_{14}\right)$ followed by the second the lowest recorded in seeds stored in polythene bag with air $\left(\mathrm{T}_{12}\right)$ after twelve months of storage.

\section{Introduction}

Onion (Allium cepa L.) is a member of family Amaryllidaceae. It is one of the major bulb crops of the world and important commercial vegetable grown all over the world and occupies a premier position amongst the vegetables due to its high preference in food, remunerative price and regular demand in the market. India ranks first in total area under onion cultivation (12.25 lakh hectares) with second largest producer (209.91 lakh million tonnes) in the world next to China, but the productivity of onion in India is very low i.e., 17.13 tonnes per ha as compared to China and other countries like, Egypt, Netherland and Iran etc.,. Hence, there is a need to enhance the productivity and production. 
Most of the onion produced in India comes from Maharashtra (28.62 \%) state followed by Karnataka (15.94 \%), Madhya Pradesh, Bihar, Gujarat Andhra Pradesh and Uttar Pradesh. Karnataka alone occupies around 195.29 thousand ha area with 2,767.98 thousand million tonnes of production and the average productivity is 16.13 tonnes per ha which is again very low compared to national productivity average.

Onion is the only vegetable in which India figures predominantly in the world for production and export. The average productivity of onion is quite low (12.82 t/ha) in India. Among the vegetables, onion seeds are classified as very poor storer, because of low availability of quality seed for planting is a major problem faced by the farmers. After the seeds are harvested, controlling seed deterioration becomes more difficult because, the seeds are much more sensitive to conditions and environments that cause loss of quality. The longevity of seeds in storage is influenced by four major factors viz., i) Genetics, ii) Quality of the seed at the time of storage, iii) Moisture content of seed or ambient RH, iv) Temperature of storage environment (Gupta, 1976). The loss of seed viability due to seed deterioration is inexorable, irreversible and inevitable but the rate of deterioration could be slowed down to a greater extent during storage by manipulating storage conditions.

Modified atmosphere storage of seeds is a suitable alternative to the use of chemical fumigants and contact insecticides that are known to leave carcinogenic residues in the treated products (Bailey and Banks, 1980). Disinfestations of stored seeds using modified atmospheric storage (MA) involves the alteration of the natural storage gases such as carbon dioxide $\left(\mathrm{CO}_{2}\right)$, oxygen $\left(\mathrm{O}_{2}\right)$ and nitrogen $\left(\mathrm{N}_{2}\right)$, to render the atmosphere in the stores lethal to pests. The MA includes neither alteration of the storage atmosphere by addition of toxic gases such as phosphate methyl bromide or regulation or alteration of the atmospheric water content. The MA may be achieved in several ways: by adding gaseous or solid $\mathrm{CO}_{2}$, by adding a gas of low $\mathrm{O}_{2}$ content (e.g., pure $\mathrm{N}_{2}$ or output from a hydrocarbon burner) or by allowing metabolic processes within an airtight storage to remove $\mathrm{O}_{2}$, usually with associated release of $\mathrm{CO}_{2}$. Such atmospheres are referred to as 'high$\mathrm{CO}_{2}$ ', 'low- $\mathrm{O}_{2}$ ' and 'hermetic storage' atmospheres, respectively. They are collectively known as 'modified atmospheres' (Banks and Fields, 1995). The effectiveness of modified atmosphere for controlling various stored product pests depends on the temperature and moisture content of the seeds, species and life storage of pests, gaseous composition and uniformity of gas distribution and exposure time of the MA treatment (Lukasiewicz et al., 1999). If the seeds are not sold in time, then it has to be carried to the next season which definitely affects the seed viability.

\section{Materials and Methods}

The laboratory experiments were conducted in the laboratory of Seed unit, University of Agricultural Sciences, Dharwad during 20162017 and the packaging of the onion seeds were carried out in the Department of Processing and Food Engineering, College of Agricultural Engineering, UAS, Raichur using the Modified Atmosphere Packaging (MAP) Unit and for cold storage seeds of particular treatment was kept in cold storage unit, department of Environmental Science, University of Agricultural Sciences, Dharwad, Karnataka.

\section{Experimental details}

The storage experiment consisted of totally 15 treatment combinations and details of the 
treatments are furnished below, out of them 12 treatments were comprised of seed storage under gaseous combinations of carbon dioxide, oxygen and nitrogen and 1 treatment in cold storage. Rest of two treatments were used to compare gaseous combinations with seeds stored cloth bag and atmospheric air in polythene bag.

\section{Details of the treatments are}

\begin{tabular}{|l|l|}
\hline Treatments & $\begin{array}{l}\text { Seed storage in different concentrations of gas } \\
\text { combinations }\end{array}$ \\
\hline $\mathbf{T}_{\mathbf{1}}$ & $80 \% \mathrm{CO}_{2}: 05 \% \mathrm{O}_{2}: 15 \% \mathrm{~N}_{2}$ \\
\hline $\mathbf{T}_{\mathbf{2}}$ & $70 \% \mathrm{CO}_{2}: 05 \% \mathrm{O}_{2}: 25 \% \mathrm{~N}_{2}$ \\
\hline $\mathbf{T}_{\mathbf{3}}$ & $60 \% \mathrm{CO}_{2}: 05 \% \mathrm{O}_{2}: 35 \% \mathrm{~N}_{2}$ \\
\hline $\mathbf{T}_{\mathbf{4}}$ & $50 \% \mathrm{CO}_{2}: 05 \% \mathrm{O}_{2}: 45 \% \mathrm{~N}_{2}$ \\
\hline $\mathbf{T}_{\mathbf{5}}$ & $40 \% \mathrm{CO}_{2}: 05 \% \mathrm{O}_{2}: 55 \% \mathrm{~N}_{2}$ \\
\hline $\mathbf{T}_{\mathbf{6}}$ & $80 \% \mathrm{CO}_{2}: 10 \% \mathrm{O}_{2}: 10 \% \mathrm{~N}_{2}$ \\
\hline $\mathbf{T}_{\mathbf{7}}$ & $70 \% \mathrm{CO}_{2}: 10 \% \mathrm{O}_{2}: 20 \% \mathrm{~N}_{2}$ \\
\hline $\mathbf{T}_{\mathbf{8}}$ & $60 \% \mathrm{CO}_{2}: 10 \% \mathrm{O}_{2}: 30 \% \mathrm{~N}_{2}$ \\
\hline $\mathbf{T}_{\mathbf{9}}$ & $50 \% \mathrm{CO}_{2}: 10 \% \mathrm{O}_{2}: 40 \% \mathrm{~N}_{2}$ \\
\hline $\mathbf{T}_{\mathbf{1 0}}$ & $40 \% \mathrm{CO}_{2}: 10 \% \mathrm{O}_{2}: 50 \% \mathrm{~N}_{2}$ \\
\hline $\mathbf{T}_{11}$ & $50 \% \mathrm{CO}_{2}: 00 \% \mathrm{O}_{2}: 50 \% \mathrm{~N}_{2}$ \\
\hline $\mathbf{T}_{\mathbf{1 2}}$ & Atmospheric air \\
\hline $\mathbf{T}_{13}$ & Vacuum \\
\hline $\mathbf{T}_{14}$ & Storage in cloth bag control \\
\hline $\mathbf{T}_{15}$ & Cold storage \\
\hline
\end{tabular}

\section{Method of modified atmosphere packaging}

Polythene bags of 700 gauge measuring 20 $\mathrm{cm}$ (length) and $14 \mathrm{~cm}$ (breadth) were used for packing purpose. In these bags, 200 grams of onion seeds were packed along with the gases like carbon dioxide, nitrogen and oxygen in different concentrations according to the treatments.

Firstly, the valves of the gas cylinders were opened and they were released at a pressure of $7 \mathrm{~kg}$ per $\mathrm{cm}^{2}$ and the different combinations of carbon dioxide, nitrogen and oxygen were mixed in the mixing chamber. According to the treatments given, the gas flow rate was controlled in the buffer tank which was directly connected to the packaging unit. 200 grams of onion seeds were packed using the packaging unit by evacuating the air and then flushed with the gases of required combinations and automatically sealed. Composition of the gas i.e., $\mathrm{O}_{2}$ and $\mathrm{CO}_{2}$ gas concentrations inside the package was checked by Check mate gas analyser with the help of septum, which prevents leakage of (head space) gas from polyethylene bag while taking readings of change in gas concentration.

\section{Procedure to use MAP instrument}

The cylinders containing Carbon dioxide $\left(\mathrm{CO}_{2}\right)$, Oxygen $\left(\mathrm{O}_{2}\right)$ and Nitrogen $\left(\mathrm{N}_{2}\right)$ gas as in Plate 1 were checked for pressure and the pressure of the gases was adjusted by following the steps detailed below.

The top dial in the mixing chamber was adjusted to the required $\mathrm{CO}_{2}$ gas concentration and the value of $\mathrm{X}$ (mentioned below the upper dial) was 
noted then adjusted the bottom dial by calculating the value of $\mathrm{N}_{2} / \mathrm{X}$ (Plate 10), where $\mathrm{N}_{2}$ is nitrogen concentration and $\mathrm{X}$ is the value or number below the upper dial.

The desired gas concentrations were checked by using check mate gas analyzer (Plate 11). Through the gas sampling port the gases were allowed to pass through needle and the obtained gas concentration from the gas mixing chamber was checked and recorded.

If the required gas concentration was not achieved then dialer was fine tuned to get the exact gas concentration. The sampling port was closed and the gas collected in the buffer tank was evacuated.

Buffer tank (Plate 12) needed to be evacuated to achieve the required gas concentration the gas was supplied through tube to the modified atmosphere packaging unit for packing of seeds.

In Packaging Unit (Plate 13) the heat level of sealing was adjusted to 2.0 to 2.5 to achieve proper sealing. The packaging material (polyethylene, 700 gauges) was kept in the packaging unit in which the vacuum was created by evacuating the air present in the packaging material and then filled the required gas concentration from buffer tank and sealed (Plate 14 and 15).

\section{Results and Discussion}

The results of different seed quality parameters like thousand seed weight, seed moisture content, seedling vigour index, seedborne infection, field emergence and electrical conductivity as influenced by modified atmospheric storage conditions and its effect during storage are presented in Table 1,2,3,4 and Figure:11.
With an advancement of storage period, the mean seed moisture content increased from $(6.10 \%)$ at the initial stage to $(6.51 \%)$ at the end of storage period, irrespective of modified atmospheric storage conditions.

Seed quality parameters differed significantly due to modified atmospheric storage conditions in all the 12 months of storage irrespective of the modified atmospheric conditions. The seeds stored in Cold storage $\left(\mathrm{T}_{15}\right)$ recorded maximum, thousand seed weight $(3.83 \mathrm{~g})$, seedling vigour index-I of $(1,394)$, seedling vigour index-II of $(1,605)$, field emergence of $(78.51 \%)$ and lowest seed borne infection of (0.0) seed moisture content $(6.11 \%)$, electrical conductivity $\left(\mathrm{d} \mathrm{Sm}^{-1}\right)$ (0.884) after twelve months of storage period followed by $\mathrm{T}_{1:}: 80 \% \mathrm{CO}_{2}: 05 \% \mathrm{O}_{2}: 15 \%$ $\mathrm{N}_{2}(72.32 \%)$ and seeds stored in vacuum $\left(\mathrm{T}_{13}\right)$. The lowest thousand seed weight $(2.63$ g), seedling vigour index-I recorded (623), seedling vigour index-II recorded (587), field emergence recorded $(40.67 \%)$ and highest seed borne infection of (37.71), seed moisture content $(8.17 \%)$, electrical conductivity $\left(1.020 \mathrm{~d} \mathrm{Sm}^{-1}\right)$ was noticed in seed stored in cloth bag $\left(\mathrm{T}_{14}\right)$ followed by the second the lowest recorded in seeds stored in polythene bag with air $\left(\mathrm{T}_{12}\right)$ after twelve months of storage.

The present study indicated that seed qualitative characters viz., thousand seed, moisture content, seedling vigour index-I and II, field emergence, seed borne infection, electrical conductivity varied significantly due to modified atmospheric store condition under ambient, cold storage and vacuum storage as individual treatments in all the months of storage period.

As the storage period advanced, all the seed quality attributes were found to be decreased. Conversely, moisture content, EC values and seed infection increased significantly 
irrespective of modified atmospheric storage conditions. Degradation of cell membrane as evidenced by higher EC values affecting the overall seed quality and loss in qualitative parameters were more acute at the end of 12 months period which could be due to ageing effect. Similar findings are also reported by Mohammad and Anjum (2002), Gao (2002) in onion.

Seeds preserved in the cold storage maintained higher seed quality because of lower respiration rate and metabolic activity as it is evidenced by higher germination $(81.01 \%)$ at the end of 12 months of storage period. While temperature and moisture content (MC) are the primary factors influencing seed longevity (Ellis and Roberts, 1980), the atmosphere surrounding the seeds can also affect storage life. The presence of oxygen is generally detrimental to seed survival at moisture content typically used inconventional seed storage (Ibrahim et al., 1983).

Higher germination up to three years in onion seeds, when the moisture content was maintained from 6.0 to $6.8 \%$ (dry treatment) or 3.6 to 3.7 (ultra dry treatment) and stored under a temperature of 2 to $20{ }^{0} \mathrm{C}$. These results are in agreement with the findings of Harrison and Carpenter (1977) in onion, Garica and Perez (1985) in onion, Egharveba and Uwadiae (1994) in Chrysophylium albidum and Rahman (1987) in tea seeds. The modified atmosphere storage of seeds with less percentage of oxygen showed retention of higher seed viability for an appreciable period. Both seed viability and vigour were well preserved with modified atmospheric storage particularly with carbon dioxide and vacuum condition.

Seeds preserved in cold storage $\left(\mathrm{T}_{15}\right)$ recorded higher seedling vigour index (Table 2) (Fig. 11 and Plate 16) which was followed by $\mathrm{T}_{1-}$ $\left(80 \% \mathrm{CO}_{2}: 05 \% \mathrm{O}_{2}: 15 \% \mathrm{~N}_{2}\right)(\%)$ and $\mathrm{T}_{13^{-}}$ vacuum compared to ambient condition $\left(\mathrm{T}_{14}\right)$. The seeds stored in cold storage were influenced by lower temperature $\left(2-4{ }^{0} \mathrm{C}\right)$ and this temperature effect might have resulted in lower respiration rate and lower metabolic activity and maintenance of higher seed vigour during storage. The probable reason for differences in storability of seeds in the modified atmospheric storage conditions might be due to the variation in the gas concentrations, where the treatment $\mathrm{T}_{1}$ having gas combination of higher $\mathrm{CO}_{2}$ with lesser percentage of oxygen concentration i.e. low oxygen atmosphere and also the seeds stored under vacuum condition showed better germination. Under the vacuum condition seed quality could be preserved even under higher temperature as reported by Barzalli et al., (2005).

Sealing helps to conserve seed quality by minimizing oxygen presence and exposure to ambient humidity, thereby keeping seed moisture content low. Seeds stored in vacuum package has recorded the next better one suggesting the role of absence of oxygen in storage followed by the treatment with combination of $75 \% \mathrm{CO}_{2}+5 \% \mathrm{O}_{2}+20 \%$ $\mathrm{N}_{2}$.

Maintenance of higher germination and vigour of seeds under these two treatments might be due to minimum fluctuation of seed moisture content and the lowest seed leachate (EC) suggesting the strong membrane integrity and minimum deterioration throughout the storage period. Higher protein content and oil content and dehydrogenase activity coupled with higher values for all the positive quality parameters were also recorded for the seeds stored in higher carbon dioxide and lower oxygen (Alvindia, 1992).

Wilson and McDonald (1986) predicted that rates of deterioration would be increased at 
high $\mathrm{O}_{2}$ levels due to depletion of protective antioxidants. This model may be especially appropriate for oil-storing seeds due to enhancement of lipid peroxidation, which can generate reactive compounds and increase membrane permeability (Bailly, 2004), McDonald (1999) suggested that eliminating $\mathrm{O}_{2}$ from the seed storage atmosphere might decrease the initiation of free radicals, which should extend seed longevity by reducing lipid peroxidation and generation of additional damaging compounds.

In keeping with this, Priestley et al., (1985) found that ground soybean seeds were more prone to lipid degradation than intact seeds in high $\mathrm{O}_{2}$ atmospheres and concluded that the intact seeds are protected against atmos autooxidation due to reduced $\mathrm{O}_{2}$ permeabunty through the seed coat.

Table.1 Effect of modified atmospheric storage conditions on thousand seed weight of onion seeds (cv. Arka Kalyan) during storage

\begin{tabular}{|c|c|c|c|c|c|c|}
\hline Treatment & \multicolumn{6}{|c|}{ Months after storage } \\
\hline $\begin{array}{lllll}\mathrm{CO}_{2} & : & \mathrm{O}_{2} & : & \mathrm{N}_{2}\end{array}$ & 2 & 4 & 6 & 8 & 10 & 12 \\
\hline $\mathrm{T}_{1}: \mathbf{8 0} \% \mathrm{CO}_{2}: 05 \% \mathrm{O}_{2}: 15 \% \mathrm{~N}_{2}$ & 3.99 & 3.96 & 3.91 & 3.86 & 3.82 & 3.78 \\
\hline $\mathrm{T}_{2}: 70 \% \mathrm{CO}_{2}: 05 \% \mathrm{O}_{2}: 25 \% \mathrm{~N}_{2}$ & 3.90 & 3.86 & 3.82 & 3.78 & 3.74 & 3.70 \\
\hline $\mathrm{T}_{3}: 60 \% \mathrm{CO}_{2}: 05 \% \mathrm{O}_{2}: 35 \% \mathrm{~N}_{2}$ & 3.86 & 3.82 & 3.78 & 3.74 & 3.70 & 3.66 \\
\hline $\mathrm{T}_{4}: 50 \% \mathrm{CO}_{2}: 05 \% \mathrm{O}_{2}: 45 \% \mathrm{~N}_{2}$ & 3.85 & 3.81 & 3.77 & 3.73 & 3.69 & 3.65 \\
\hline $\mathrm{T}_{5}: 40 \% \mathrm{CO}_{2}: 05 \% \mathrm{O}_{2}: 55 \% \mathrm{~N}_{2}$ & 3.81 & 3.77 & 3.73 & 3.69 & 3.65 & 3.61 \\
\hline $\mathrm{T}_{6}: \mathbf{8 0} \% \mathrm{CO}_{2}: 10 \% \mathrm{O}_{2}: 10 \% \mathrm{~N}_{2}$ & 3.83 & 3.79 & 3.75 & 3.71 & 3.67 & 3.63 \\
\hline $\mathrm{T}_{7}: 70 \% \mathrm{CO}_{2}: 10 \% \mathrm{O}_{2}: 20 \% \mathrm{~N}_{2}$ & 3.79 & 3.75 & 3.71 & 3.67 & 3.63 & 3.59 \\
\hline $\mathrm{T}_{8}: 60 \% \mathrm{CO}_{2}: 10 \% \mathrm{O}_{2}: 30 \% \mathrm{~N}_{2}$ & 3.77 & 3.73 & 3.69 & 3.65 & 3.61 & 3.57 \\
\hline $\mathrm{T}_{9}: 50 \% \mathrm{CO}_{2}: 10 \% \mathrm{O}_{2}: 40 \% \mathrm{~N}_{2}$ & 3.76 & 3.72 & 3.68 & 3.64 & 3.60 & 3.56 \\
\hline $\mathrm{T}_{10}: 40 \% \mathrm{CO}_{2}: 10 \% \mathrm{O}_{2}: 50 \% \mathrm{~N}_{2}$ & 3.74 & 3.70 & 3.66 & 3.62 & 3.58 & 3.54 \\
\hline $\mathrm{T}_{11}: \mathbf{5 0 \%} \mathrm{CO}_{2}: \mathbf{0 0} \% \mathrm{O}_{2}: \mathbf{5 0} \% \mathbf{N}_{2}$ & 3.88 & 3.84 & 3.80 & 3.76 & 3.72 & 3.68 \\
\hline $\mathbf{T}_{12}$ : Atmospheric air & 3.82 & 3.63 & 3.50 & 3.07 & 3.00 & 2.70 \\
\hline$T_{13}:$ Vacuum & 3.97 & 3.95 & 3.90 & 3.83 & 3.79 & 3.75 \\
\hline $\mathbf{T}_{14}:$ Storage in cloth bag (control) & 3.80 & 3.59 & 3.30 & 3.01 & 2.86 & 2.63 \\
\hline$T_{15}:$ Cold storage & 3.99 & 3.98 & 3.97 & 3.94 & 3.90 & 3.83 \\
\hline Mean & 3.84 & 3.78 & 3.71 & 3.63 & 3.58 & 3.50 \\
\hline S.Em. \pm & 0.01 & 0.01 & 0.01 & 0.01 & 0.01 & 0.01 \\
\hline C.D. @ 1\% & 0.02 & 0.02 & 0.02 & 0.02 & 0.02 & 0.03 \\
\hline
\end{tabular}

(Initial 1000 Seed weight: $3.99 \mathrm{~g}$ ) 
Table.2 Effect of modified atmospheric storage conditions on seedling vigour index-II of onion seeds (cv. Arka Kalyan) during storage

\begin{tabular}{|c|c|c|c|c|c|c|}
\hline \multirow{2}{*}{$\begin{array}{l}\text { Treatment } \\
\mathrm{CO}_{2}: \mathrm{O}_{2}: \quad \mathrm{N}_{2}\end{array}$} & \multicolumn{6}{|c|}{ Months after storage } \\
\hline & 2 & 4 & 6 & 8 & 10 & 12 \\
\hline $\mathrm{T}_{1}: 80 \% \mathrm{CO}_{2}: 05 \% \mathrm{O}_{2}: 15 \% \mathrm{~N}_{2}$ & 2,195 & 2,110 & 1,983 & 1,810 & 1,628 & 1,429 \\
\hline $\mathrm{T}_{2}: 70 \% \mathrm{CO}_{2}: 05 \% \mathrm{O}_{2}: 25 \% \mathrm{~N}_{2}$ & 2,149 & 2,064 & 1,939 & 1,769 & 1,590 & 1,393 \\
\hline $\mathrm{T}_{3}: 60 \% \mathrm{CO}_{2}: 05 \% \mathrm{O}_{2}: 35 \% \mathrm{~N}_{2}$ & 2,142 & 2,057 & 1,932 & 1,762 & 1,583 & 1,387 \\
\hline $\mathrm{T}_{4}: 50 \% \mathrm{CO}_{2}: \mathbf{0 5} \% \mathrm{O}_{2}: 45 \% \mathrm{~N}_{2}$ & 2,140 & 2,055 & 1,930 & 1,760 & 1,581 & 1,386 \\
\hline $\mathrm{T}_{5}: 40 \% \mathrm{CO}_{2}: 05 \% \mathrm{O}_{2}: 55 \% \mathrm{~N}_{2}$ & 2,128 & 2,044 & 1,919 & 1,750 & 1,571 & 1,376 \\
\hline $\mathrm{T}_{6}: 80 \% \mathrm{CO}_{2}: 10 \% \mathrm{O}_{2}: 10 \% \mathrm{~N}_{2}$ & 2,133 & 2,048 & 1,923 & 1,754 & 1,575 & 1,379 \\
\hline $\mathrm{T}_{7}: 70 \% \mathrm{CO}_{2}: 10 \% \mathrm{O}_{2}: 20 \% \mathrm{~N}_{2}$ & 2,121 & 2,037 & 1,912 & 1,743 & 1,565 & 1,370 \\
\hline $\mathrm{T}_{8}: 60 \% \mathrm{CO}_{2}: 10 \% \mathrm{O}_{2}: 30 \% \mathrm{~N}_{2}$ & 2,113 & 2,029 & 1,905 & 1,736 & 1,558 & 1,363 \\
\hline $\mathrm{T}_{9}: 50 \% \mathrm{CO}_{2}: 10 \% \mathrm{O}_{2}: 40 \% \mathrm{~N}_{2}$ & 2,108 & 2,024 & 1,900 & 1,732 & 1,554 & 1,359 \\
\hline $\mathrm{T}_{10}: 40 \% \mathrm{CO}_{2}: 10 \% \mathrm{O}_{2}: \mathbf{5 0} \% \mathrm{~N}_{2}$ & 2,103 & 2,018 & 1,895 & 1,726 & 1,549 & 1,355 \\
\hline $\mathrm{T}_{11}: \mathbf{5 0 \%} \mathrm{CO}_{2}: \mathbf{0 0} \% \mathrm{O}_{2}: \mathbf{5 0} \% \mathrm{~N}_{2}$ & 2,145 & 2,060 & 1,935 & 1,765 & 1,586 & 1,389 \\
\hline$T_{12}:$ Atmospheric air & 2,086 & 1,886 & 1,607 & 1,266 & 920 & 587 \\
\hline $\mathbf{T}_{13}:$ Vacuum & 2,156 & 2,071 & 1,945 & 1,775 & 1,595 & 1,398 \\
\hline$T_{14}:$ Storage in cloth bag (control) & 2,013 & 1,816 & 1,550 & 1,216 & 879 & 555 \\
\hline$T_{15}:$ Cold storage & 2,213 & 2,144 & 2,036 & 1,905 & 1,761 & 1,605 \\
\hline Mean & 2,124 & 2,023 & $\mathbf{1 , 8 7 7}$ & 1,683 & 1,481 & 1,266 \\
\hline S.Em. \pm & 17.15 & 16.73 & 15.95 & 15.03 & 14.01 & 12.86 \\
\hline C.D. @ 1\% & 47.16 & 46.01 & 43.86 & 41.32 & 38.53 & 35.36 \\
\hline
\end{tabular}

(Initial seedling vigour index-II: 2,275) 
Table.3 Effect of modified atmospheric storage conditions on field emergence per cent of onion seeds (cv. Arka Kalyan) during storage

\begin{tabular}{|c|c|c|c|c|c|c|}
\hline \multirow{2}{*}{\begin{tabular}{l}
\multicolumn{3}{c}{ Treatment } \\
$\mathrm{CO}_{2}: \mathrm{O}_{2}: \mathrm{N}_{2}$
\end{tabular}} & \multicolumn{6}{|c|}{ Months after storage } \\
\hline & 2 & 4 & 6 & 8 & 10 & 12 \\
\hline $\mathrm{T}_{1}: 80 \% \mathrm{CO}_{2}: 05 \% \mathrm{O}_{2}: 15 \% \mathrm{~N}_{2}$ & 89.82 & 87.32 & 84.32 & 79.82 & 75.82 & 69.82 \\
\hline $\mathrm{T}_{2}: 70 \% \mathrm{CO}_{2}: 05 \% \mathrm{O}_{2}: 25 \% \mathrm{~N}_{2}$ & 89.77 & 87.27 & 84.27 & 79.77 & 75.77 & 69.77 \\
\hline $\mathrm{T}_{3}: 60 \% \mathrm{CO}_{2}: 05 \% \mathrm{O}_{2}: 35 \% \mathrm{~N}_{2}$ & 89.50 & 87.00 & 84.00 & 79.00 & 75.67 & 69.50 \\
\hline $\mathrm{T}_{4}: \mathbf{5 0 \%} \mathrm{CO}_{2}: \mathbf{0 5} \% \mathrm{O}_{2}: 45 \% \mathrm{~N}_{2}$ & 89.25 & 86.83 & 83.75 & 79.50 & 75.50 & 69.25 \\
\hline $\mathrm{T}_{5}: 40 \% \mathrm{CO}_{2}: 05 \% \mathrm{O}_{2}: 55 \% \mathrm{~N}_{2}$ & 88.85 & 86.35 & 83.35 & 78.85 & 74.85 & 68.90 \\
\hline$T_{6}: 80 \% \mathrm{CO}_{2}: 10 \% \mathrm{O}_{2}: 10 \% \mathrm{~N}_{2}$ & 89.00 & 86.50 & 83.50 & 79.00 & 75.00 & 69.00 \\
\hline $\mathrm{T}_{7}: 70 \% \mathrm{CO}_{2}: 10 \% \mathrm{O}_{2}: 20 \% \mathrm{~N}_{2}$ & 88.55 & 86.05 & 83.05 & 78.55 & 74.55 & 68.70 \\
\hline $\mathrm{T}_{8}: 60 \% \mathrm{CO}_{2}: 10 \% \mathrm{O}_{2}: 30 \% \mathrm{~N}_{2}$ & 88.25 & 86.25 & 82.75 & 78.25 & 74.42 & 68.25 \\
\hline $\mathrm{T}_{9}: 50 \% \mathrm{CO}_{2}: \mathbf{1 0} \% \mathrm{O}_{2}: 40 \% \mathrm{~N}_{2}$ & 88.15 & 85.65 & 82.65 & 78.15 & 74.45 & 68.15 \\
\hline $\mathrm{T}_{10}: 40 \% \mathrm{CO}_{2}: 10 \% \mathrm{O}_{2}: 50 \% \mathrm{~N}_{2}$ & 88.00 & 85.50 & 82.50 & 78.67 & 74.00 & 68.00 \\
\hline $\mathrm{T}_{11}: \mathbf{5 0 \%} \mathrm{CO}_{2}: \mathbf{0 0} \% \mathrm{O}_{2}: \mathbf{5 0} \% \mathrm{~N}_{2}$ & 89.42 & 86.92 & 83.92 & 79.42 & 75.42 & 69.42 \\
\hline$T_{12}$ : Atmospheric air & 87.50 & 81.67 & 74.17 & 64.67 & 54.17 & 40.67 \\
\hline$T_{13}:$ Vacuum & 89.67 & 87.17 & 84.17 & 79.67 & 75.67 & 69.67 \\
\hline $\mathbf{T}_{14}:$ Storage in cloth bag (control) & 86.67 & 80.67 & 73.67 & 64.17 & 53.67 & 40.17 \\
\hline$T_{15}:$ Cold storage & 90.36 & 88.61 & 86.51 & 84.01 & 82.01 & 78.51 \\
\hline Mean & 88.74 & 85.80 & 82.15 & 76.96 & 72.07 & 64.95 \\
\hline S.Em. \pm & 0.44 & 0.45 & 0.43 & 0.44 & 0.44 & 0.43 \\
\hline C.D.@1\% & 1.21 & 1.23 & 1.18 & 1.22 & 1.20 & 1.19 \\
\hline
\end{tabular}

(Initial field emergence: $92.01 \%$ ) 
Table.4 Effect of modified atmospheric storage conditions on moisture content per cent of onion seeds (cv. Arka Kalyan) during storage

\begin{tabular}{|c|c|c|c|c|c|c|}
\hline Treatment & \multicolumn{6}{|c|}{ Months after storage } \\
\hline $\mathrm{CO}_{2}: \mathrm{O}_{2}: \mathrm{N}_{2}$ & 2 & 4 & 6 & 8 & 10 & 12 \\
\hline $\mathrm{T}_{1}: 80 \% \mathrm{CO}_{2}: 05 \% \mathrm{O}_{2}: 15 \% \mathrm{~N}_{2}$ & 6.12 & 6.11 & 6.13 & 6.14 & 6.16 & 6.17 \\
\hline $\mathrm{T}_{2}: 70 \% \mathrm{CO}_{2}: 05 \% \mathrm{O}_{2}: 25 \% \mathrm{~N}_{2}$ & 6.16 & 6.17 & 6.18 & 6.19 & 6.21 & 6.21 \\
\hline $\mathrm{T}_{3}: 60 \% \mathrm{CO}_{2}: 05 \% \mathrm{O}_{2}: 35 \% \mathrm{~N}_{2}$ & 6.17 & 6.18 & 6.19 & 6.22 & 6.25 & 6.22 \\
\hline $\mathrm{T}_{4}: 50 \% \mathrm{CO}_{2}: 05 \% \mathrm{O}_{2}: 45 \% \mathrm{~N}_{2}$ & 6.19 & 6.21 & 6.21 & 6.21 & 6.24 & 6.24 \\
\hline $\mathrm{T}_{5}: 40 \% \mathrm{CO}_{2}: 05 \% \mathrm{O}_{2}: 55 \% \mathrm{~N}_{2}$ & 6.20 & 6.21 & 6.22 & 6.24 & 6.25 & 6.27 \\
\hline $\mathrm{T}_{6}: 80 \% \mathrm{CO}_{2}: 10 \% \mathrm{O}_{2}: 10 \% \mathrm{~N}_{2}$ & 6.20 & 6.27 & 6.22 & 6.23 & 6.27 & 6.26 \\
\hline $\mathrm{T}_{7}: 70 \% \mathrm{CO}_{2}: 10 \% \mathrm{O}_{2}: 20 \% \mathrm{~N}_{2}$ & 6.23 & 6.23 & 6.25 & 6.26 & 6.30 & 6.28 \\
\hline $\mathrm{T}_{8}: 60 \% \mathrm{CO}_{2}: 10 \% \mathrm{O}_{2}: 30 \% \mathrm{~N}_{2}$ & 6.24 & 6.24 & 6.26 & 6.28 & 6.31 & 6.32 \\
\hline $\mathrm{T}_{9}: 50 \% \mathrm{CO}_{2}: 10 \% \mathrm{O}_{2}: 40 \% \mathrm{~N}_{2}$ & 6.25 & 6.27 & 6.34 & 6.30 & 6.31 & 6.31 \\
\hline $\mathrm{T}_{10}: 40 \% \mathrm{CO}_{2}: 10 \% \mathrm{O}_{2}: 50 \% \mathrm{~N}_{2}$ & 6.26 & 6.27 & 6.28 & 6.29 & 6.30 & 6.33 \\
\hline $\mathrm{T}_{11}: 50 \% \mathrm{CO}_{2}: \mathbf{0 0} \% \mathrm{O}_{2}: \mathbf{5 0} \% \mathrm{~N}_{2}$ & 6.17 & 6.19 & 6.19 & 6.20 & 6.21 & 6.22 \\
\hline $\mathbf{T}_{12}$ : Atmospheric air & 7.67 & 8.47 & 9.00 & 8.80 & 8.40 & 7.93 \\
\hline$T_{13}:$ Vacuum & 6.10 & 6.11 & 6.12 & 6.12 & 6.14 & 6.16 \\
\hline$T_{14}:$ Storage in cloth bag (control) & 8.40 & 9.73 & 9.50 & 9.30 & 8.70 & 8.17 \\
\hline$T_{15}:$ Cold storage & 6.10 & 6.11 & 6.10 & 6.11 & 6.10 & 6.11 \\
\hline Mean & 6.45 & 6.62 & 6.65 & 6.63 & 6.57 & 6.51 \\
\hline S.Em. \pm & 0.02 & 0.02 & $\mathbf{0 . 0 2}$ & $\mathbf{0 . 0 2}$ & $\mathbf{0 . 0 2}$ & 0.04 \\
\hline C.D.@1\% & 0.06 & 0.05 & 0.05 & 0.06 & 0.06 & 0.11 \\
\hline
\end{tabular}

(Initial moisture content: $6.10 \%$ )

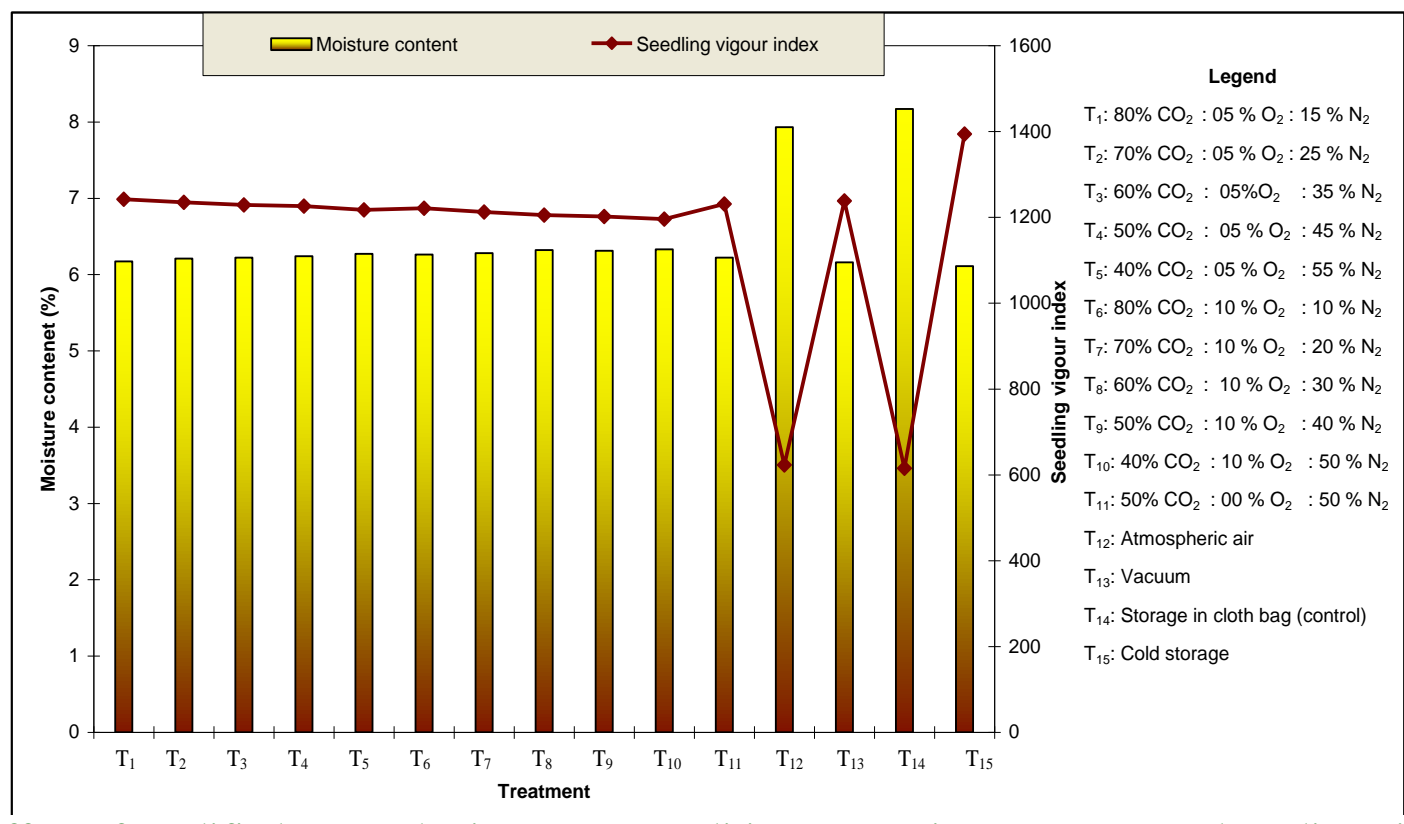

Fig.1 Effect of modified atmospheric storage conditions on moisture content and seeding vigour index of onion seeds (c.v. Arka Kalyan) during storage 

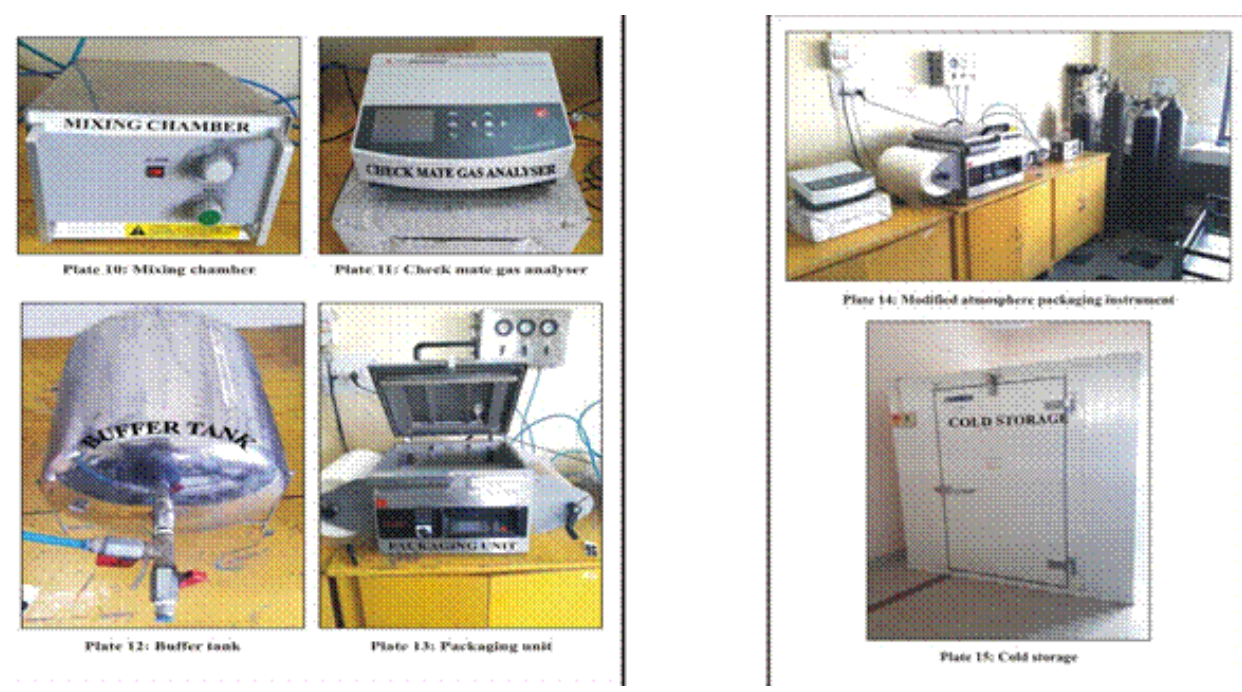

Plate.1 Mixing Chamber, Check mate gas analyser, Buffer TankPackaging, Packaging unit, Method atmosphere packaging instrument and Cold storage

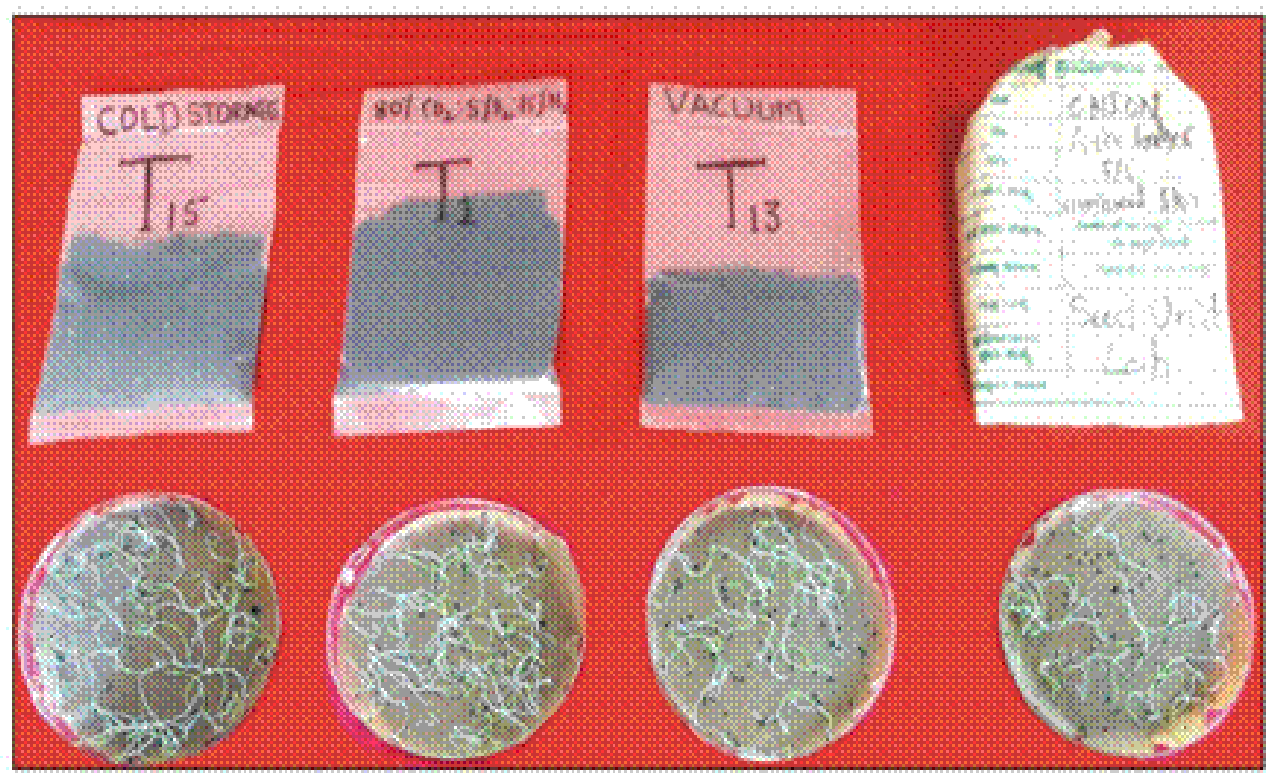

Plate.2 Packaging under modified atmospheric storage and respective seed germination potential at the end of $12^{\text {th }}$ montjhs of storage in onion cv. Arka Kalyan

The $\mathrm{CO}_{2}$ adsorption phenomenon observed in rice seed storage in a $\mathrm{CO}_{2}$ atmosphere was assumed to be caused by a mechanism combined with a diffusion process in the embryo and a carbamate formation of $\mathrm{CO}_{2}$ gas with functional groups of protein which are exposed in the internal surface of the embryo. The reversible interaction of $\mathrm{CO}_{2}$ gas was assumed to contribute to retaining seed qualities during storage (Yamamoto and
Mitsuda, 1980). However the other combinations of $\mathrm{CO}_{2}, \mathrm{O}_{2}$ and $\mathrm{N}_{2}$ were also performed in acceptable manner exclusively with better germination per cent and vigour especially later half part of storage. The seeds stored in normal air irrespective of containers (cloth or polythene bag) recorded lesser germination and vigour while compared to seeds stored in modified concentration of gases revealing the deterioration effect of air 
which contains highest concentration of $\mathrm{O}_{2}$ and lowest concentration of $\mathrm{CO}_{2}$. The higher percentage of mycoflora, the higher accumulation of free fatty acids and loss of germinability accompanied by mould growth (Christensen and Kauffman, 1969) was observed when seeds were placed under natural ageing. Soybean storage, which is safety enough for 12 months or its deterioration retarded, can be done by using vacuum and plastic bag and the moisture content at beginning of around 8 per cent.

Their deterioration also reflected in increase in moisture content higher EC values, presence of pathogen and decrease in oil and protein content of seeds. This result is in conformity with the findings of Shelar (2002) who reported that the mycoflora of soybean seed increased with subsequent increase in storage period, irrespective of variety, threshing and processing methods and storage containers. However, certain fungi, bacteria, viruses and insects are not removed and they cause or hasten seed deterioration (Justice and Bass, 1979).

The modified atmospheric storage conditions showed significant effect on vigor and viability of onion seeds. The seeds which stored in cold storage $\left(\mathrm{T}_{15}\right)$ showed better vigor throughout the storage period followed by seeds stored with gaseous combination of $80 \% \mathrm{CO}_{2}: 05 \% \mathrm{O}_{2}: 15 \% \mathrm{~N}_{2}\left(\mathrm{~T}_{1}\right)$ and under vacuum conditions $\left(\mathrm{T}_{13}\right)$ under ambient storage conditions.

Among the storage conditions tested, the seeds preserved under cold storage recorded higher field emergence and seedling vigor index with less qualitative loss in comparisons to those seeds stored under ambient condition i.e. in cloth bag throughout the storage period of 12 months. The study clearly indicated the importance of onion seed storage under cold storage and higher $\mathrm{CO}_{2}$ and lowest $\mathrm{O}_{2}$ for maintenance of seed quality during storage. In case of absence of this facility even seed storage under vacuum is quite satisfactory. The deleterious effect of seeds stored in impervious container and higher oxygen concentration was revealed during the study.

\section{References}

Bailly, C., 2004, Active oxygen species and antioxidants in seed biology. Seed Sci. Res., 14: 93-107.

Banks, J. and Fields, P., 1995, Physical methods for insect control in storedgrain ecosystems. In: Stored- Grain Ecosystems (Jayas, D. S.; White, N. D. G; Muir W. E, Eds), pp 353-410.Marcel Dekker, Inc., New York.

Christensen, C. M. and Kauffman, H. H., 1969, In: Grain Storage. Univ. of Minnesota, Minneapolis, p. 153.

Egharveba, R and Uwadiae, P., 1994, The effect of different storage conditions on germination and growth of two varieties of chrysophylium albidium. Negerian J. For., 24-25: 119-123.

Ellis, R. H. and Roberts, E. H., 1980, Improved equation of the prediction of seed longevity. Ann. Bot., 45: 13-30.

Gao, W. H., 2002, Effect of storage temperature and seed moisture on germination of seeds. Pl. Phy. Comm., 38(4):339-340

Garica, A. G. and Perez, R. C., 1985, Factors which influence loss of germination of onion seed (Allium cepa L.) during storage. Horticultura Mexicana, 1: 15-26.

Harrison, B.J. and Carpenter, R., 1977, Storage of Allium cepa seed at low temperatures. Seed Sci. Technol., 5: 699-702

Ibrahim, A. E., Roberts, E. H. and Murdoch, A. J., 1983, Viability of lettuce seeds. II. Survival and oxygen uptake in 
osmotically controlled storage. J. Exp. Bot., 34: 631-40.

Justice, O. L. and Bass, L. N., 1979, Principals and Practices of Seed Storage. Castle House Publication Ltd. London.

Lukasiewicz, M., Jayas, D. S., Muir, W. E. and White, N. D. G., 1999, Gas leakage through samples of Wall seams of bolted-metal bins. Canadian Agril. Eng., 41 (1): 25-28.

McDonald, M. B., 1999, Seed deterioration. Physiology, repair and assesment. Seed Sci. Technol., 27: 177-237.

Mohammad, A. and Anjum, M. A., 2002, Evaluation of physiological quality of onion seed stored for different periods. Int. J. Agric., Bio., 4(3):365-369

Rahaman, F., 1987, Studies on cold storage of tea seed. J. Plantation Crops, 15 (2): 142-143.

Shelar, V. R., 2002, Soybean seed infection by the microflora during the storage period. Ph.D. Thesis, Mahatma Pule Krishi Vignyan Kendra, Rahuri, Maharashtra (India).

Wilson, D. O. Jr. and McDonald, M. B. Jr., 1992, Mechanical damage in bean (Phaseolus vulgaris L.) seed in mechanized and non-mechanized threshing systems. Seed Sci Technol., 20: 571-582.

Yamamoto, A. and Mitsuda, H., 1980, Characteristics of carbon dioxide gas adsorption by grain and its components. Controlled atmosphere storage of grains [Shejbal, J. (Editor)] 1980 pp. 247-258.

\section{How to cite this article:}

Koteshi Lamani, V. K. Deshpande, N. K. Biradar Patil and Shashidhar. T. R. 2020. Effect of Modified Atmospheric Packaging on Seed Longevity of Onion (Allium cepa L.) cv. Arka Kalyan. Int.J.Curr.Microbiol.App.Sci. 9(03): 198-209. doi: https://doi.org/10.20546/ijcmas.2020.903.024 